\title{
STRUGGLING WITH EVIL: COMMENTS ON WANDERING IN DARKNESS
}

\author{
JOHN MARTIN FISCHER \\ University of California, Riverside
}

\section{INTRODUCTION AND PRELIMINARIES}

This is a compendious book on the problem of evil that brings together insights from a broad range of intellectual disciplines (including not just philosophy and theology, but also psychology, neuroscience, and literature) in a beautiful and powerful way. Even if it does not ultimately succeed in providing an entirely convincing reply to the problem of evil, it is nevertheless a significant and impressive achievement. Stump offers nuanced, original, and often brilliant interpretations of central Biblical narratives about suffering, and she also lays out a comprehensive and appealing argument for the conclusion that God's existence is compatible with the nature and extent of human suffering we find in our world. The two parts of the book - the exegeses of Biblical stories and the philosophical argument - are meant to work together and to complement each other.

I have learned a great deal by reading this book. Stump has managed to write a book that is both magisterial and humane. The details are subtle and the argumentation is sometimes intricate, and one can learn much about specific philosophical and theological topics along the way. And in the end it adds up to something big: a Thomistic defence of God's existence, based on analytical argumentation (the Dominican approach) and the humanizing force of stories (Franciscan knowledge).

There is so much to this book that a reviewer must inevitably select just a relatively small portion of it on which to focus, and this is what I shall do. What is perhaps not inevitable - and yet I will succumb to the temptation - will be a selection of a few topics that are of special 
interest to me. This will leave much of this immense and rich book for other commentators and readers to explore. I commend it as both a challenging and also a deeply engaging experience.

Stump emphasizes that she seeks to provide a 'defence', rather than a 'theodicy'. This distinction was introduced by Alvin Plantinga, and although it is tolerably clear, a single, precise characterization of the distinction has not emerged in the subsequent literature. ${ }^{1}$ Often a 'defence' is taken to be an attempt to show that the existence of God (as conceived in a certain way) is not logically incompatible with the suffering that exists in our world. But the charge that evil (or evil of the sort we find in our world) is logically inconsistent with God's existence is not often pressed these days, and it is perhaps too easy simply to establish the logical compatibility of God's existence and evil (of the sort that we find in our world). We would typically want something more than a 'defence' in this very weak sense; we would want an account in which God and also the sort of suffering that we have in the actual world exist, where the account meets certain further 'epistemic requirements.' Stump suggests such a requirement in the following:

It has to be the case that, for all we know (as distinct from all that we are committed to believing), the claims of a defense could be true. It would therefore invalidate a defense if something about what we currently know demonstrates that the possible world of the defense is not the actual world. (p. 454)

The suggestion here is that the account in which both God and the relevant sorts of evil are said to exist must be consistent with what is 'known'. Stump makes it clear that she here intends that what is known be interpreted as the uncontroversial empirical truths. This still seems to me to be a rather weak epistemic requirement. That is, the requirement here would simply be that the account be logically compatible with the uncontested empirical truths.

A somewhat stronger requirement is suggested by Van Inwagen. Instead of simply requiring that the account be compatible with the uncontested empirical truths, Van Inwagen also requires that, given theism, we have no (good or strong) reason to think that the account

${ }^{1}$ I am indebted to the very thoughtful and helpful critical notice of Stump's book by William Hasker: 'Light in the Darkness? Reflections on Eleonore Stump's Theodicy', Faith and Philosophy, 28 (4) (October 2011), pp. 432-50, esp. pp. 432-5.

${ }^{2}$ I am here following Hasker, 'Light in the Darkness?', p. 434. 
is false. ${ }^{3}$ In his insightful review of Stump's book, Hasker offers Van Inwagen's epistemic requirement as a friendly amendment to Stump, and he interprets her as seeking to offer a defence that would meet Van Inwagen's requirement. ${ }^{4}$ Hasker contends that only a defence that meets this more robust epistemic requirement could be part of (or on the way to) a theodicy. As Hasker puts it, '... if we have that much, then the defense is at least a candidate for being a theodicy, a true account of the reasons that God is justified in permitting suffering. ${ }^{35}$

I pause here to offer a passage from David Lewis's fascinating paper, 'Evil for Freedom's Sake?', in which Lewis also suggests that the most promising project for a theist is to offer something in between a defence (in the weak sense) and a full theodicy:

... Defense is too easy; knowing God's mind is too hard. I think the topic worth pursuing falls in between, and has no place in Plantinga's scheme of theodicy versus defence. Pace Plantinga, I'll call that topic 'theodicy', but I don't mean the know-it-all theodicy that he wisely disowns. Rather I mean tentative theodicy, even speculative theodicy. The Christian needn't hope to end by knowing for sure why God permits evil. But he can hope to advance from a predicament of not having a clue to a predicament of indecision between several not-too-unbelievable hypotheses (maybe still including the hypothesis: 'none of the above'). ${ }^{6}$

Perhaps Lewis would agree with Hasker's proposal that what is wanted is a defence that is at least a candidate for a theodicy. In any case Lewis correctly notes that a defence in Plantinga's sense seems too weak. We can perhaps in a rough and ready way place the views about adequacy criteria for defences along a spectrum as follows. We start with the weakest constraint on what would count as an adequate defence and proceed to more stringent requirements: Plantinga (logical compatibility of God's existence and evil of the sort in the actual world); Stump (logical compatibility of God's existence and evil of the sort in the actual world, given uncontested empirical truths); and Van Inwagen/Hasker (logical compatibility of God's existence and evil of the sort in the actual world,

${ }^{3}$ Peter Van Inwagen, 'The Problem of Evil, the Problem of Air, and the Problem of Silence, Philosophical Perspectives, 5, Philosophy of Religions (1991), 135-65; the quotation is from p. 156, cited by Stump on p. 16.

${ }^{4}$ Hasker, 'Light in the Darkness?', p. 435.

${ }^{5}$ Hasker, 'Light in the Darkness?', p. 435.

${ }^{6}$ David Lewis, 'Evil for Freedom's Sake?', Philosophical Papers, 22 (1993), 149-72; the quotation is from p. 151. 
and no reason to think the account false, given theism). The idea behind the requirement that there be no reason to think the account false, given theism, is that God's existence should fit with the existence of evil in a plausible way. That is, we should not have a good or strong reason to think that the story of why God allows the evil in question is false.

\section{OVERVIEW OF STUMP'S DEFENCE}

At the risk of great oversimplification, I shall offer a brief summary of the philosophical argument that provides the core of the Dominican part of Stump's defence. ${ }^{7}$ This part of Stump's defence is heavily influenced by St. Thomas Aquinas. She begins by laying out a scale of value presented by St. Thomas, according to which the best thing for a human person is to have union with God (a personal relationship of love), and the worst thing is the absence of such union. Following Paul Draper's helpful summary, we can now regiment the argument as follows; we can think of it as applying to an arbitrary human person. (1) God loves the person and so desires the relevant kind of union with her - a personal relationship of love. (2) Such union is impossible even for God, given that a person is not in a state of psychic integration around the good. (3) To achieve such integration, the person needs to undergo a process of 'justification and sanctification', which is a gradual process of harmonizing (with God's help) the person's global desire for a will that wills the good with her other desires. (4) But - and this is important - the best means available to God to promote that process is to cause or allow the individual to suffer.

On Stump's Thomistic defence, God loves us and this leads him (given that we are psychologically constituted as we are and disposed to desire and choose certain things) to cause (or allow) us to suffer; so, on this picture, human suffering is conceptualized along the lines of 'tough love' given by a parent who is guided by the best interests of the child. Perhaps it would be unfair to characterize God's role here as like a 'Tiger Mom', since such a parent has a quite expansive view of the sorts of suffering that are good for the child. It is fairer to Stump's project to acknowledge that she is onto something deep, resonant, and attractive: an interpretation of our

\footnotetext{
${ }^{7}$ Here, and elsewhere, I have benefited from the extremely insightful critical notice of Stump's book by Paul Draper, "Wandering in Darkness: Narrative and the Problem of Suffering”, reviewed by Paul Draper', Notre Dame Philosophical Reviews. Available at: $<$ http://ndpr.nd.edu/news/24772-wandering-in-darkness-narrative-and-the-problemof-suffering/> [accessed: 03/09/2012].
} 
suffering as countenanced by a powerful and well-meaning parent-like figure who is guided by our long-term flourishing. Additionally, Stump's interpretation of The Book of Job suggests that God's communications with Job impart via Franciscan means the message that God is there for Job, like a well-meaning (if somewhat absent, or, at least, apparently absent) parent. (It must be admitted that, even if God is there in some sense for Job, Job is still a bit of a 'latch-key kid'.) The human need for a parent-like figure to look after us is very pervasive and deep, in my view.

I am reminded of a recent conversation with my brother. Our parents had just called him on the phone, and from all appearances, the call was both short and perfunctory. They didn't really seem to me to be sharing much information at all. When I asked my brother what that was about, he replied that ever since the day he was diagnosed with a particularly nasty form of non-Hodgins' lymphoma, they had called him every day. Since the treatment had been successful and he has done well for four years, the calls have become increasingly short; but our parents have still called literally every day. At that point I understood that the call had indeed conveyed something deeply important - perhaps as much content as can ever be conveyed, although not of the Dominican sort.

My brother, sister, and I are fortunate; we have wonderful and loving parents. How even more wonderful it would be if I could believe that the whole universe - including, most notably (from my perspective), me - were looked after by an all-powerful and all-loving parent-like figure. Mark Ravizza - my philosophical collaborator and friend, who is now a Jesuit priest - once told me that he had a deep need to believe that the world is looked after by a good and powerful force. I have often wished that I could have precisely this sort of view (answering to the need); I have felt that Mark and others who can actually believe this (based on their way of evaluating the evidence) have a kind of deep consolation and comfort that I lack.

In any case, one might wonder about what exactly the relationship is between the Dominican part of the defence - the Thomistic defence and the Franciscan part, in Stump's view. I very much like Paul Draper's suggestion here:

Stump is acutely aware of just how alien (or medieval) the world of the defense will seem to her readers, given contemporary secular and even religious sensibilities. She recognizes that her views are at risk of being dismissed out of hand. To prevent that from happening, she must make an 
appeal to both hemispheres of our brains, not just to the left hemisphere. Thus, the defense itself must have two hemispheres, a left one consisting of a description of St. Thomas's worldview and theodicy, and a right one consisting of the Biblical narratives.... In the case of the right hemisphere of the defense, what is needed is philosophically motivated literary analysis designed to make the defense come alive in a psychologically or interpersonally realistic way in the Biblical narratives. ... Unless the stories can show the 'Franciscan possibility' of a world in which God and human beings grow closer through suffering, all the philosophical argument in the world is unlikely to make Stump's audience take the defense seriously. ${ }^{8}$

As noted above, Stump is at pains to claim that her project is to provide a defence, rather than a theodicy. I also noted above that there is some unclarity about what exactly an adequate defence would involve, and even some unclarity about what Stump herself is seeking in this respect. I shall here simply point to some general concerns I have about the project of offering a mere defence, as opposed to a theodicy, and then reflect in a preliminary way on how these concerns bear on Stump's project.

\section{SPARTAN DEFENCES AND THE NATURE OF A DEFENCE}

I share David Lewis's worry that a defence doesn't really give us much - and certainly not as much as we - at least many of us - would (or should) want. One way to get at this concern is to ask about whether we couldn't have a different, much simpler 'defence' that meets the criteria of adequacy for a defence laid out by Plantinga, Stump, Van Inwagen, and Hasker. We could ask why these simpler strategies don't already give us a defence (of the indicated sort). And if they do, what exactly is added by a more elaborate defence of the sort provided by Stump? And in light of the apparent fact that these pared-down models meet the relevant adequacy criteria for defences, we can ask whether any defence really provides what we should want, as we struggle with the relationship between human suffering and God's existence. Further, if these minimalist stories do not constitute defences, then how is it that Stump's story does indeed count as a defence?

So here's a really spare defence. God has a certain 'matrix' he uses to apportion happiness in heaven. More specifically, and for some reason

\footnotetext{
${ }^{8}$ Ibid., p. 6.
} 
unknown to us, God gives people much more happiness in heaven, or perhaps is much more likely to assign persons to heaven, insofar as they have suffered unjustly in their lives on Earth. As in Sceptical Theism, we do not have access to God's reasons for this feature of his 'matrix'. We might suggest various hypotheses for why God's matrix is as it is, but we just do not have full access to God's reasons here. Of course, we know that God has some reason for the relevant feature of the matrix; we just don't know what it is.

I do not see why this very abstract model is not a 'defence': here God's existence would seem to be logically compatible with suffering - at least I do not see why it would obviously not be. And it would seem that, on this model, God's existence would be compatible with human suffering, given uncontested empirical truths; further, God's existence would be logically compatible with human suffering, and there would seem to be no good or strong reason to think any aspect of the account false, given theism. Insofar as the spare model won't really help much for most people struggling with the relationship between the manifest facts of human suffering and the putative existence of God, it seems to me that merely providing a defence is too little. That is, the spare model is really unsatisfying - and yet it would seem at least arguably to be a defence, according to all of the criteria presented above.

Perhaps someone will deny that my spare model does indeed present a defence; they will contend that the picture of God it presents is not of a morally perfect being. After all, on this story God allows us to suffer and then 'makes it up to us' in the afterlife. But just because God makes it up to us does not show that allowing us to suffer on Earth was justified in the first place. The only way that this picture would be compatible with God's perfect goodness is if there is some good reason why people have to suffer on Earth, it might be urged. ${ }^{9}$ I agree that there are mysteries here, but I am supposing - along the lines of Sceptical Theism - that there are indeed good reasons why God allows the suffering of the innocent on Earth, even if we humans don't have full access to them. Of course, various reasons might be proposed. I am simply positing that God has such reasons, even though we do not fully grasp them. While perhaps it is not obvious that the story I have told is logically coherent (and thus a defence), I would also claim that it is not obvious that the story is logically incoherent. (I will return to this point below.)

${ }^{9} \mathrm{I}$ am very grateful to Patrick Todd for this point. 
We could fill in the bare model a bit, along the lines suggested by Alvin Plantinga's defence. Suppose that there is an angel - with free will - who is in charge of implementing God's will with respect to the apportioning of happiness in heaven (or perhaps assigning slots in heaven). For some reason inaccessible to us, the angel in charge of such matters has decided (of his or her own free will) to apportion much more happiness in the afterlife to those who have suffered unjustly in their lives on Earth. As in Plantinga's defence, God does not intervene to supersede this angel's free will, which God prizes highly. Of course, the mechanism of apportionment of happiness in the afterlife is here filled in slightly more than in my first proposal, but it is still a very simple, pareddown defence. Again, I do not see why it doesn't meet all the adequacy criteria for defences. So, for example, this model seems to present a story in which God's existence is logically compatible with human suffering of the sort we find in the actual world, and, given theism, there is no reason to think that the story is false (or has a false element).

One might worry that the account is not logically consistent, since God could intervene to prevent the angel from implementing the angel's preferred 'function' inversely relating worldly and post-mortem flourishing. One might also worry about why God put this sort of angel in charge of these matters in the first place. But if such worries would imply that my proposed defence is logically inconsistent, it would also presumably show that Alvin Plantinga's purported defence is similarly logically inconsistent. That is, just as one would need a further account of why God would allow the angel to implement her preferred function, so Plantinga would need an account of why God would allow the relevant devils to exercise their free will. The problem with Plantinga's defence is typically not thought to be that it presents a logically inconsistent picture; rather, the problem is that it is thought to be too weak. John Perry (through the characters in his dialogue on the problem of evil) offers a defence that involves specific devils in charge of causing suffering due to specific kinds of calamities, such as fires, floods, tornadoes, earthquakes, and so forth. The devils freely choose their role, and God values their free will. ${ }^{10}$ It seems to me that my proposed defence is logically on a par with those

${ }^{10}$ John Perry, Dialogue on Good, Evil, and the Existence of God (Indianapolis, Indiana: Hackett Publishing Co., 1999); reprinted in Perry, Bratman, and Fischer, eds., Introduction to Philosophy: Classical and Contemporary Readings, 5th Edition (New York: Oxford University Press, 2010), pp. 96-119. 
of Plantinga and Perry; if mine is no defence, then the same fate would await the defences presented by Plantinga and Perry.

I pointed out above that one might worry that the spare story with which I began is logically inconsistent insofar as God is supposed to be morally perfect and thus would not be inclined to adopt the sort of matrix I suggested. Similarly, one might worry that God is supposed to be omnipotent and thus could adopt whatever matrix he wished or supersede any angel's freedom of the will in this matter. But I would observe that one could equally worry whether Stump's defence is logically consistent. This is because she contends that we are by our nature psychically fragmented in such a way as not to admit of union with God without the process of justification and sanctification, and further that suffering is the best means available (even to God) for achieving the desired union. But why did God, being omnipotent, create us with such a nature? And why couldn't an omnipotent God have created us such that we didn't need pain and suffering, or so much of it, to get us ready for union with God? ${ }^{11}$ I claim that, at the very least, my stories are just as likely as Stump's to be consistent. So, for example, I claim that there is some reason, even if we do not have access to it, why God's matrix is as it is (in my story). But Stump must similarly contend that there is some reason, even if we do not have access to it, why God made us such that we need pain in order to be ready to have union with him.

Of course, I have only sketched 'defences' in the most minimal way. But even so, I think we can at least pose the question whether the spare models I have proposed are indeed defences, or core components of defences. They seem to be, in the Plantinga, Stump, and Van Inwagen/ Hasker senses of 'defence.' And if so, isn't a defence just too little to offer to many sincere people struggling with the problem of evil? Further, if indeed the spare models are defences, we might ask what Stump's richer and more detailed account adds. Again: Stump emphasizes repeatedly that her project is not to offer a theodicy, but, rather, a defence; but if this is the project, aren't there much simpler, more straightforward defences? Clearly, there is nothing that demands that there be just one or just a few defences, or just one or a few styles of defence; Stump may

${ }^{11}$ Draper makes this point in his NDPR review, writing, 'There's no reason, however, why an omnipotent being would need to use suffering as a causal means of giving us that power [to allow God to be close or closer]. Such a being could simply directly cause us to have it or set up the world in such a way that something more benign than suffering works just as well as suffering in producing the crucial power.' 
contend that she is providing $a$ defence - one among many possible kinds of defences. This is obviously perfectly legitimate, but it does raise the question (again) of whether simply providing a defence - even a rich and elaborate one - really gets one very far (or far enough). If a detailed, rich, and elaborate story gets us to the same point as the spare accounts sketched above, what exactly is the philosophical payoff of the richer, more detailed defence?

One could say that the richer kind of story told by Stump is easier to meld with the Biblical narratives and thus can have easier or better access to the synergism of Franciscan and Dominican elements. But I am not sure that this really is the case, as it would seem that we could invoke the Franciscan knowledge on behalf of the bare stories, as well as the richer account given by Stump. The Franciscan knowledge is a way of getting in touch with the deeply resonant idea that God is like a very powerful and perfectly benevolent parent looking after us, so that, even if it may not appear this way to us, our suffering is ultimately in our interest. (Of course, the Franciscan knowledge is not reducible to this point, but can perhaps be understood as a distinctive and ineffable way of gaining access to it.) But if this is very roughly correct, then we could invoke Franciscan knowledge on behalf of the spare models as well. After all, a perfectly knowledgeable, powerful, and good parent would be concerned to maximize our flourishing over our entire existence (and not just our earthly existence), and such a God would arguably respect the free will of angels and devils, as well as human beings. Indeed, Stump's fascinating discussions of God's conversations with Satan (in her highly original interpretation of $J o b$ ) indicate that, on her view, God cares about all his creatures, including refractory angels and devils; and in any case, it seems that he must respect their free will (at least if Plantinga's and Perry's defences really are defences, and, additionally, for independent reasons).

I am interested to know what Stump would say about these questions. I do think she has offered an account that captures important features of St. Thomas's worldview and theodicy, and this in itself is no small feat. Further, the richness of the detail of Stump's picture makes it helpful insofar as it can be embedded in a more complete picture of human nature, as well as a specific worldview (both philosophical and theological). My main concern, I suppose, is that, in the end, even if it is indeed a defence, her more elaborate story is only a defence (in the senses of Plantinga, Stump, and Hasker/Van Inwagen). 
Perhaps I could put my lingering dissatisfaction as follows. The Problem of Evil is, at its fundamental level, about how to fit God with evil. A defence is one way to address this problem: one assumes that God exists, and tells a story that purports to explain how God's existence fits with evil (of the nature and extent of evil in the actual world). A defence then will be of primary interest to someone who already believes in God, or is inclined to, or who thinks that there are strong 'positive' reasons to believe in God - perhaps one of, or a combination of, the traditional arguments for the existence of God. A defence then would be a way of 'playing defence', as it were.

But there is also what is sometimes called, following William Rowe, the 'Evidential Problem of Evil. Although (as with 'defence') there is perhaps no settled-upon meaning of 'Evidential Problem of Evil', the problem is roughly that, setting aside evidence for the existence of God, the nature and extent of evil in our world suggests that it is unlikely or implausible that God exists. This is, of course, a very different way of raising the problem of how God's existence and evil fit together; here we do not begin by assuming God's existence and seek to tell a coherent and even perhaps plausible story about evil. Rather, we bracket arguments for the existence of God, and we consider whether the evil of our world constitutes evidence that God's existence is unlikely. As far as I can see, none of the defences we have considered, including Stump's, provides any answer to the Evidential Problem of Evil. Of course, this is not to say that anyone who addresses the Problem of Evil must or even should address the Evidential Problem. Clearly, there are different parts or aspects of the Problem of Evil, and correspondently different target audiences for a response.

I myself am not antecedently inclined to accept theism, and I am gripped by the notion that the nature and extent of both human and animal suffering in our world renders it unlikely that God exists. (Note that, surprisingly, Stump does not address the issue of animal suffering, which some might find particularly troubling and difficult to reconcile with God's existence; I am not sure how Stump would extend her model to address the problem of animal suffering. $)^{12}$ Thus, I would be interested

${ }^{12}$ It might seem that Stump must here appeal to something more general that will in turn give a further explanation of why God allows humans to suffer, since it is implausible that being in a relationship with God is the greatest good for an animal. This explanation might then supersede the reasons she has already adduced, so her defence would not turn on God's desiring certain kinds of meaningful relationships with us, but with some 
in not just a defence, but also a theodicy. And I would be interested in a response to the Evidential Problem of Evil. That is, I would like to see a bit more offence, and not just defence. ${ }^{13}$ Again: it is not reasonable to demand that a theorist address all of these difficult issues, and this does not constitute a critique of Stump's substantial and important book. Rather, I am simply trying to situate her project and to identify the source of my lingering sense - difficult perhaps fully to articulate that the story presented by Stump leaves some pressing and distressing challenges untouched. ${ }^{14}$

\section{THEISM SHOULD NOT HANG ON A THREAD}

Finally, I wish to point to what I take to be a strike against Stump's Thomistic defence. (Of course, I realize that one gets three strikes, at least in baseball.) Elsewhere, and without securing universal and enthusiastic agreement (!), I have argued that it is a strike against libertarianism that our freedom and moral responsibility 'hang on a thread'; they are held hostage to the possible empirical discovery of the truth of causal determinism. I think our moral responsibility and status as persons should not be so tenuous; it should not depend on whether or not causal determinism turns out to be true. My view is not that our moral responsibility should not depend on any empirical contentions; rather, I would argue that our moral responsibility should not depend on this sort of empirical thesis about the world.

Additionally, I believe that a belief in God should not depend on whether causal determinism is true. I don't think that a belief in God should hang on a thread - that it should be held hostage to the theoretical physicists in this particular way. So, for example, if a believer in God should awake to the New York Times headline, 'Causal Determinism is True!!!', I do not think that this should lead him to give up his theism (or

further fact that explains that as well as why he would allow animals to suffer as they do. I am grateful to Justin Coates for this point.

${ }^{13}$ Vince Lombardi, the former coach of the Green Bay Packers, famously said, 'The best defense is a good offense.' This quotation can be traced back to the military strategist, Carl von Clausewitz.

${ }^{14}$ A defence will not be of interest only to someone who already believes in God. Suppose, for instance, that someone finds the arguments for the existence of God quite persuasive, but the problem of evil keeps her from being a theist (i.e., endorsing God's existence), because she thinks there is no adequate response to the problem of evil. Or suppose someone thinks theists are just crazy, as it were, given the problem of evil. A defence could move this person. I am grateful to Patrick Todd for this point. 
even his subscription to the Times!). Just as it is awkward or dialectically infelicitous or just plain uncomfortable to have our moral responsibility and personhood hang on a thread in this way, so it would be similarly uncomfortable to have one's theism depend on the deliverances of the theoretical physicists (in this specific manner).

And yet, as Stump points out, her Thomistic defence presupposes what she calls (using a term Van Inwagen and I unite in disparaging) 'libertarian freedom'. Here what is meant is at least that agents must have freedom to do otherwise, because it is manifest that so many individuals fail to benefit in the indicated ways (through justification and sanctification) from their suffering. If we look at the world and note this, how is it not an indictment of God? The answer, according to the Thomistic defence proposed by Stump, is that even those individuals who do not benefit from their suffering and turn freely to God have the power to do so; although they fail to achieve union with God, God has provided them the required resources, and they have freely failed to take advantage of their opportunity. But it is plausible that if causal determinism were true, then no human person would have the freedom to do other than he or she actually does. For various reasons, it is plausible to suppose that causal determinism must be false, in order for individuals to have freedom to do otherwise. Thus, the defence presupposes the falsity of causal determinism, along with human freedom to do otherwise. And, on this sort of defence, we would apparently have to give up a belief in God, if causal determinism were true. Belief in God would hang on a thread. I take it that this at least counts against Stump's proposed defence.

I concede that the issues here are delicate - both in respect of my contention that our status as morally responsible agents should not hang on a thread and also that a belief in God should not similarly hang on a thread. Much more would need to be said to make the case for these claims. I simply want here to stake out a view to the effect that it is at least somewhat unfortunate - a factor that militates to some extent against a defence - that it makes our belief in God hinge on the falsity of causal determinism - an empirical doctrine that could, for all we know, turn out to be true. ${ }^{15}$ In my view, it would be nice to have a compatibilist-friendly

${ }^{15}$ A proponent of theism might insist that causal determinism is necessarily false, given the existence of a God who has the power to intervene in the world, and thus the doctrine is not an empirical doctrine at all. Note that even if this is so, it would imply that a defence that posited a God that sets up the world but cannot intervene subsequently would still have the problem of rendering God's existence dependent on the falsity of 
defence. This way one would not have to dig in one's heals and ignore the physicists, if they really do some day discover the truth of causal determinism, and one would not have to give up one's belief in God. As Peter Van Inwagen once said in an informal conversation in which I suggested this point, 'Yes, it would be like having a theodicy in your breast pocket, which you could pull out if causal determinism were to be shown to be true.' A compatibilist theodicy would in this respect be like an insurance policy designed to minimize one's dialectical risks, as it were. Right, and I believe that such a defence can indeed be constructed, but it is a project for another occasion - one I very much hope to pursue in the future. This project will employ the idea - that Stump herself accepts - that moral responsibility does not indeed require alternative possibilities; additionally, it will employ other compatibilist ingredients, as well as features of libertarian theodicies that can be detached from the supernumerary libertarianism.

\section{CONCLUSION}

As I wrote above, Eleonore Stump's book is truly a magisterial combination of analytical philosophy and a humane sensibility. Please allow me to say that throughout her career Professor Stump has been an exemplar of both of these qualities: a rigorous, incisive, and broadly knowledgeable analytical philosopher, as well as a warm, supportive, and thoughtful friend. ${ }^{16}$

causal determinism. Further, although I do not have the space to argue for this view here, I do not think that the move in question - positing the necessary falsity of causal determinism - really helps with the problem of religious belief hanging on a thread. This is because it might be true that causal determination holds in a sequence, assuming that God does not intervene. And, I would argue, this would be bad enough, in part because the only way to sever the connection between the past and the relevant behaviour would be a via a direct intervention by God. But these matters demand a more careful and comprehensive treatment.

${ }^{16}$ I have benefited greatly from discussions with, and comments by, Justin Coates and Philip Swenson. I am particularly grateful to detailed, challenging, and highly insightful comments on various drafts by Patrick Todd. Finally, I found the Author-Meets-Critics Session at the American Philosophical Association, Pacific Division, Meetings in Seattle, Washington (USA) in April, 2012 both congenial and illuminating. On that occasion David McNaughton also offered comments, and Eleonore Stump replied to both of us. In part to avoid being a moving target, and at the risk of being a 'piñata grande', I resist the temptation to revise significantly in light of the comments at this session. 